\title{
Digital Rights for the Digitally Literate Citizens
}

\author{
Daniela Zivkovic, Ph.D., Assoc. Prof. \& Aleksandra Horvat, Ph.D., Prof. \\ Faculty of Humanities and Social Sciences \\ University of Zagreb, Croatia \\ Email: $\underline{\text { daniela.zivkovic1@ @g.htnet.hr \& ahorvat@ffzg.hr }}$ \\ Vesna Cucic, Ph.D. \\ Dubrovnik Libraries, Croatia \\ Email: vesna.cucic1@du.t-com.hr
}

\begin{abstract}
The aim of this paper is to show that the digital literacy should be understood in a much broader sense than it is now and that its full achievement is impossible if new digital rights are not introduced in the society and understood and accepted by the citizens. To prove their presumption that little is known about digital rights even among students the authors had conducted a small-scale research among LIS and non-LIS students at two different universities in the country, University of Zagreb and University of Dubrovnik. On the basis of findings authors concluded that LIS educators and librarians have special responsibilities as regards digital rights: educators should reformulate study programmes and incorporate the topic of digital rights, while librarians should strive to speak for their users and incorporate the users' rights into library legislation.
\end{abstract}

Keywords: digital literacy, digital rights, LIS education, library legislation, Croatia.

\section{Introduction}

In 2010 the new European strategy Europe 2020 [1] was launched by the European Commission in order to prepare the European economy and European societies for the next decade. The Strategy acknowledges a key role of information and communication technologies and deals with it further in a document entitled $A$ Digital Agenda for Europe [2] in which proposals for action that need to be taken by 2020 are made. All public and commercial services should become available in the digital environment. Much of the content accessible today in cultural institutions such as libraries, archives and museums should also become available in the digital format. To achieve this the Digital Agenda envisages the creation of trustworthy and secure environment, fast and ultrafast Internet access and enhancement of digital literacy and skills of citizens. The implementation of the aims of the Digital Agenda will certainly have a serious impact on European citizens. Closely linked to the Digital Agenda is Horizon 2020 [3], a new research and innovation programme, due to start in 2014, which reiterates the need for the development of inclusive, innovative and secure societies and emphasizes the need to ensure cyber security, trust and privacy. The prerequisite for digital inclusiveness is the acquirement of digital literacy. The aim of this paper is to show that the digital literacy should be understood in a much broader sense than it is now and that its full achievement is impossible if new digital rights are not introduced in the society and understood and accepted by the citizens.

\section{Digital literacy}

According to Bawden [4] the term digital literacy first appeared in the 1990's and was used to denote an ability to read and understand hypertextual and multimedia texts. Further meanings of the term developed over time and it has also been used to convey the meaning of traditional literacy (reading, writing and understanding) in a new digital surrounding. However, it should be kept in mind that the term appears along with a multitude of similar terms what might contribute to uncertainty and insecurity in its use. 
Sometimes it is used interchangeably with terms like information literacy, media literacy, Internet literacy or even AV literacy [5], [6], [7], [8]. Bowden [4] goes on to show how the terms information literacy, computer literacy, library literacy, media literacy, network literacy, Internet literacy and digital literacy have gradually been introduced into use since 1980 and provides an extensive interpretation of the meanings of those terms based on a survey of professional literature. The appearance of various kinds of skill-based literacies in recent years is often related with the increasing complexity of information and the technological development. However some authors point out that literacies should not be considered as skill-based only, because they are also related to acquiring knowledge. Some authors emphasize the importance of critical thinking in assessing information as a constituent part of literacy. Dobson and Willinsky [5] state that digital literacy has democratic qualities because it allows everyone not only to read, i.e to receive, but also to send, i.e. to speak out and make one's views widely available. For Koltay [7] acquiring different literacies means feeling comfortable with all media and developing a critical approach as regards the quality and accuracy of content. He defines digital literacy as an ability to read and understand information from a variety of digital sources. But he also emphasizes and to our mind rightly so, that apart from reading and understanding, the ability to publish and communicate information should be a part of digital literacy. Sourbati [6] describes the drive for universal access to services in the European Union and rightly comments that access to the Internet is a broader concept than service. Therefore physical access to the Internet and connectivity are not adequate to fully understand the media use. According to her access policies have to be reformulated on the local basis for certain groups of population. A more recent and extensive survey of scholarly literature on new literacies was made by Potter [9]. According to him authors use the terms more or less as they suit the purpose of their papers. Speaking about media literacy he states that it should be understood as political, social and cultural practice. Apart from developing skills it requires acquiring knowledge about the digital surrounding.

More and more often authors investigating media literacy or digital literacy agree that physical access to the Internet and developing computer and communication skills are not sufficient to achieve digital literacy. Acquiring knowledge about the digital surrounding appears as a legitimate constituent part of digital literacy [8].

In this paper the authors will attempt to show that digital literacy based on a set of skills and knowledge needed by an individual to feel at ease in the digital surroundings also requires determining and agreeing on certain rights belonging to every participant in the society. The EU idea of inclusive societies and the importance of making citizens digitally literate in order to be able to receive services is acceptable on condition that those who seek and receive those services know the conditions surrounding the provision of services. However, this seems not to be the case at present, because individuals either use the services offered without an adequate knowledge of the consequences of their acts, or as in the case of e-books, a service cannot be obtained at all.

\section{Digital rights}

Digital rights may mean different things to different people. Postigo [10], for instance, describes the US situation and the development of digital rights movement organizations which take stand in specific cases when individuals have been taken to court by the content industry allegedly for the infringement of the law in the digital environment. However, the term is prevalently used to denote the rights that allow individuals to access, use, create, and publish digital media or to access and use computers, other electronic devices, or communication networks. The term is particularly related to the protection and realization of existing human rights, such as the right to privacy or freedom of expression, in the context of new digital technologies, especially the Internet [11]. The EU documents often use the term, but strangely enough in its 2012 Code of EU online rights [12] the word online (not digital) was used. The Code contains the basic set of rights and principles enshrined in EU law that protect citizens when accessing and using online networks and services. It is not enforceable in itself, but serves as a sort of reminder that certain rights are guaranteed to the citizens, but are scattered across various directives, regulations and conventions. A set of rights applicable in the digital environment have been described by Horvat \& Zivkovic [13] who write about the right to access the Internet, right to speak freely, right to privacy and right to be forgotten. Some of those rights have been considered to be basic human rights and have been known and accepted for some time, while the others, like the right to be forgotten [14], have been introduced only recently as concepts and have yet to be adopted in practice. Similarly the right to access e-books in libraries is a new concept born in 
the library circles after the publishers decided to deny access to e-books to library users. If this right is indeed denied the traditional role of the library will be negated and its future becomes uncertain. Therefore we believe that this particular right deserves a more detailed explanation.

\section{Right to access e-books}

At its recent annual conference held in Copenhagen in May 2012, EBLIDA stated that libraries and citizens have very few rights due to the current situation in e-book market and consequently launched the European Campaign for e-books in libraries [15]. The aim was to draw the attention of politicians and citizens of the European Union to the disadvantages for libraries and their users. This action was heavily driven by the fact that publishers were reluctant to recognize libraries as customers of their e-books which could be lent to library users. At approximately the same time IFLA released a background paper on e-lending [16]. It set as its task to identify e-lending models that provide the broadest possible access to e-books in keeping with traditional library values of collection development, user privacy and freedom of access to information. In 2013 IFLA put forward Principles for library elending together with Principles for the licensing/purchase and use of ebooks in libraries [17].

It is a fact that the property rights model for print books is hard to apply to e-books although it is generally agreed that e-book should include both digital nature of the e-book and analogy to printed book. However, the concept of acquisition and use of e-book indicates growing divergence from the printed book concept for which the property rights model is characteristic. E-book buyers visiting collections at the e-book platforms are normally granted the license to access e-books and only rarely can they buy a digital copy which becomes their property. Distribution rights for e-books are defined by the location of online buyer, while for analogue books a physical place of sale is crucial. In order to achieve the favourable and consequently competitive environment for e-books worldwide distribution rights for e-books purchased online should be established and interoperability of formats across e-book platforms achieved. Cloud-based access to streamed e-book content will certainly increase accessibility of such content. E-books should be accessible and the critical aspects of its use, like copyright and privacy of readers, should be solved.

Accessibility depends on pricing which is conditioned by taxation like value added tax. Policy makers should consider harmonising the VAT rate across physical and digital media for books. They also have to determine whether e-book is a service or a product. The fixing of e-book prices by publishers as an instrument to protect culturally valuable content and diversity applying restrictions to free market forces is under consideration in both the US and the EU. Language diversity of e-book collections also appears to be a prerequisite for digital literacy.

\section{Investigation}

To prove or possibly refute the presumption that little is known about digital rights even among students, who could rightly be regarded as the true Internet generation, a small-scale investigation was conducted among LIS and non-LIS students at two different universities in the country in May 2013. Students were chosen as the targeted group because they use the Internet in both their education and recreation and are likely to possess necessary digital skills for its use. A questionnaire was developed in order to learn about their attitudes and expectations in the digital environment. Optional responses were offered to speed up the process of filling out the questionnaire. The population investigated consisted of two groups: 68 students of LIS enrolled at the Zagreb University and 28 students of Art and Restoration studies at Dubrovnik University. A pilot study was conducted in January 2013 among 27 students of Zagreb University in order to test the questions in the questionnaire and consequently some questions were slightly changed. As no significant differences in responses were found between LIS and non-LIS students a decision was taken to present the overall results in this paper. It should be emphasized here that the sample of respondents is by no means conclusive for the whole student population in the country, but it is representative of respective classes of LIS students at Zagreb University and students of Art and Restoration at Dubrovnik University and the findings might hopefully be a guidance to their teachers.

Students were first asked about the time they spent daily on the Internet. The overall number of hours spent on the Internet confirms the important role it has in satisfying the students' needs for education, recreation and information. More than one third of respondents reply that they spend between 3-5 hours per day on the Internet and not one spends less than 2 hours. Asked if the Internet should be accessible to all the majority of them $(89.6 \% ; \mathrm{n}=86)$ agree, less than $10 \%$ choose $n o$ for reply. It appears that students take it for granted 
that the Internet is open to all and its contents accessible free of charge. But when asked who has the right to control it, they are divided in opinions: a little less than one third of students $(27.1 \%$; $n=26)$ would allow the government to control the Internet, approximately one third $(37.5 \% ; \mathrm{n}=36)$ would give parents the right to control the contents used by their children, $14.6 \%(\mathrm{n}=14)$ agree that employers have that right, $25 \%$ $(n=24)$ is against anyone's control, while slightly less than $20 \%(n=19)$ cannot provide an answer. Although well aware of possible intrusions on their privacy they are active members of social networks (78.1\%; $n=75$ are members of Facebook); nevertheless the majority of them (72.9\%; n=70) limit the access to friends only, although according to their comments they are well aware that this restriction is insufficient to provide privacy. $64.6 \%(\mathrm{n}=62)$ agree that harmful content should be removed from the Internet, $26 \%$ $(n=25)$ do not agree. Many of them add their comments, e.g. everything has to be accessible, examples of hate speech too; hate speech is an ambiguous concept; who will decide what is harmful; a person herself should choose intelligent and useful content.

Asked if they download music from the Internet the overwhelming majority $(90.6 \% ; n=87)$ reply that they do. Films are downloaded by $85.4 \%(n=82)$ of the students. Only a few $(8.3 \% ; n=8)$ state that they do not do it and add a comment such as: it is immoral, or such act shows lack of respect for performers, etc. At the same time $86.5 \%$ of respondents $(\mathrm{n}=83)$ have never paid for downloaded music or films.

The aim of the questions related to the e-book use was to find out whether students use e-books on the Internet at all and if they do under what conditions. $62.5 \%(\mathrm{n}=60)$ use free e-books, $28.1 \%(\mathrm{n}=27)$ use the password provided by the institution for the access, $1.04 \%(\mathrm{n}=1)$ pay for the access and $22.9 \%(\mathrm{n}=22)$ do not use e-books. $94.8 \%(n=91)$ do not have own e-book readers, while only $4.16 \%(n=4)$ have them.

\section{Discussion and conclusion}

The limited sample of respondents do not allow for broader conclusions. However, to our mind the answers obtained reflect well the general attitudes of young Internet users in the country. The Internet is considered to be free and open to all and it should be so. The existence of harmful content is acknowledged, but opinions about whether it is justified to remove harmful content are divided. The content used is also regarded as basically free and if certain use requires payment, this is evaded. It is probably appropriate here to refer to the new "right to share" initiative of the organization Article 19 from April 2013. In the words of the organization it is a right needed to balance copyright and freedom of expression [18]. It should be mentioned here that the right to share is certainly not among rights mentioned in the EU Code of online rights, and that the use of copyright protected content without authorization and payment is a critical issue in the EU countries, as the recent adoption of the so-called three-strikes legislation in some member countries clearly shows.

Students learn about privacy on the social network, they understand its shortcomings, but tacitly accept the rules provided by the owner of the network. It should be borne in mind that owners of social networks are private corporations who determine the rules of the behaviour on the network. Newspapers and internet portals report daily about dangers posed by the Internet and about users and even representatives of the governments who request removal of incorrect or unfavourable material and do not succeed. [19]. Right to be forgotten should be implemented and users should learn about it as their right. As concerns student population we can only plead that information on personal data protection and guidance on the behaviour on the net is introduced in the curriculum of LIS, but also non-LIS studies.

Students' replies concerning the use of e-books and possession of e-readers point to a low use of both ebooks and the equipment needed for its use in the country. There are several Croatian e-book platforms available but students mostly prefer to access or download free of charge and do not decide to buy an ebook which includes the online purchase and provision of access to e-books. Again, this finding is found to be correlated to the low level of digital literacy but it can also be related to the government policy on scientific research. Namely, Croatian academic community is supplied with considerable subject collections of international titles in electronic formats through access and licensing models chosen and paid for by the Croatian Ministry of Science, Education and Sports. Libraries outside academe in Croatia are mostly involved in activities to allow access to local digital content already owned by them and to less extent in developing platforms for managing e-books purchased from rightholders. In the Science and Technology Policy the Croatian Government supports open access to publicly funded scientific information. Educational institutions opted for open access even before the Croatian Declaration on Open Access that was presented in October 2012 and is accessible at the Hrcak (Hamster), open access scientific journal portal, that today hosts 330 Croatian scientific and professional journals. 
Schools and universities are ideal places where knowledge of digital rights could be acquired. LIS educators have special responsibilities as regards digital rights; they should reformulate curricula and incorporate the topic of digital rights into them. On the other hand practicing librarians should strive to speak for library users and incorporate the users' rights into library legislation.

\section{References}

1. Europe 2020: a European Strategy for Smart, Sustainable and Inclusive Growth, http://ec.europa.eu/eu2010/ (2010)

2. A Digital Agenda for Europe, http://ec.europa.eu/information_society/digital-agenda/documents/digital-agendacommunication-en.pdf (2013)

3. Horizon 2020: The Framework Programme for Research and Innovation, COM (2011) 808final. European Commission (2011)

4. Bawden, D. Information and Digital Literacies : A Review of Concepts. J. Documentation 57, 2, 218-259 (2001)

5. Dobson, T., Willinsky, J.: Digital literacy. In: Olson, D., Torrance, N. (eds.) Cambridge Handbook on Literacy. Cambridge University Press, Cambridge, UK (2009), http://pkp.sfu.ca/files/Digital\%20Literacy_0.pdf

6. Sourbati, M.: Media literacy and universal access in Europe. The Information Society, 25, 4, 248--254 (2009)

7. Koltay, T.: The Media and the Literacies: Media Literacy, Information Literacy, Digital Literacy. In: Media, Culture and Society 33,2, 211--221 (2011)

8. Chen, D., Wu, J., Wang, Y.: Unpacking new media literacy. J. Systemics, cybernetic \& Informatics 9,2, 84-88 (2011)

9. Potter, W. J.: The State of Media Literacy. In: J. Broadcasting \& Electronic Media (2010)

10. Postigo, H.: The Digital Rights Movement: the Role of Technology in Subverting Digital Copyright. MIT, Cambridge, Mass, (2013)

11. Digital Rights. In: Wikipedia, http://en.wikipedia.org/wiki/Digital_rights (2013)

12. Code of EU Online Rights. Publications Office of the European Union, Luxembourg (2012), https://ec.europa.eu/digital-agenda/sites/digitalagenda/files/Code\%20EU\%20online\%20rights\%20EN\%20final\%202.pdf

13. Horvat, A., Zivkovic, D.: Izmedju javnosti i privatnosti: knjiznice u vremenu e-knjige (Between the public and the private: libraries in the e-book age). Hrvatska sveucilisna naklada, Zagreb (2012)

14. Proposal for a regulation of the European Parliament and of the Council on the protection of individuals with regard to the processing of personal data and on the free movement of such data (General Data Protection Regulation), http://ec.europa.eu/justice/data-protection/document/review2012/com_2012_11_en.pdf (2012)

15. E-books in Libraries Campaign, http://www.eblida.org/e-books-in-libraries.html (2012)

16. IFLA Background Paper on e-Lending, http://www.ifla.org (2012)

17. IFLA and Library eLending, http://www.ifla.org/files/assets/hq/topics/elending/ifla_principles_for_library_elending_april_2013.pdf (2013)

18. Art. 19 Right to share, http://ipkitten.blogspot.co.uk/2013/04/article-19-launches-right-to-share-to.html (2013)

19. Matyszczyk, C.: Google's Shmidt: Teens Mistakes Will Never Go Away. In: CNET News

http://news.cnet.com/8301-17852_3-57586206-71/googles-schmidt-teens-mistakes-will-never-go-away/ (2013) 
